\title{
Epidermis structure in Mesembryanthemaceae
}

\section{H. -D. IHLENFELDT*}

\section{ABSTRACT}

The Mesembryanthemaceae, which inhabit the deserts and semi-deserts of Southern Africa, exhibit two very different types of epidermis. The first is characterized by thick outer cell walls encrusted by oxalate crystals, a thick cuticle and thick wax layers. In the second type, the epidermal cells exhibit only very thin outer cell walls, not encrusted by oxalate crystals, a very thin cuticle, and wax layers are poorly developed; the most prominent feature of this type is the occurrence of huge idioblasts often protruding as 'bladder cells'. With regard to the climatic conditions in the native habitats this type of epidermis must be called 'abnormal'.

Both types of epidermis may form sculptures of three distinct size classes, which are not necessarily homologous. The function of these sculptures is still poorly understood. There is evidence that the sculptures influence the optical properties of the surfaces and thereby the radiation balance (and heat stress) of the leaves.

From recent research, it has become evident that the two different types of epidermis are the anatomical expression of two different strategies for survival under extreme conditions. Species with the idioblast type of epidermis exhibit a strategy that might be called 'opportunistic'. These species have developed a mechanism of gaining water from the atmosphere during the night under favourable conditions. There are indications that the idioblasts are involved in this mechanism.

\section{RESSUÉ}

\section{STRUCTURE DE L'ÉPIDERME CHEZ LES MESEMBRYANTHÉMACÉES}

Les Mésembryanthémacées qui habitent les déserts et semi-déserts de l'Afrique australe montrent deux types d'épiderme très différents. Le premier est caractérisé pas des cloisons cellulaires extérieures épaisses incrustées de cristaux d'oxalate, une épaisse cuticule et des couches épaisses de cire. Dans le second type, les cellules de l'épiderme montrent seulement des cloisons cellulaires extérieures très minces, non incrustées de cristaux d'oxalate, une très fine cuticle et des couches de cire pauvrement développées; le trait le plus saillant de ce type est la présence de grands idioblastes, souvent proéminents sous forme de cellules vésiculées. Par rapport aux conditions climatiques prévalant dans leur habitats d'origine ce type d'épiderme doit être appelé 'anormal'.

Les deux types d'épidermes peuvent former des sculptures de trois classes de taille distinctes, qui ne sont pas nécessairement homologues. La fonction de ces sculptures est encore mal connue. Il est prouvé que ces sculptures influencent les propriétés optiques des surfaces et de ce fait, l'équilibre de la radiation (et la tension de chaleur) des feuilles.

Des recherches récentes ont démontré que les deux types d'épidermes sont l'expression anatomique de deux stratégies différentes pour la survivance sous des conditions extrêmes. Les espèces avec le type d'épiderme à idioblastes montrent une stratégie que l'on peut qualifier 'd'opportuniste'. Ces espèces ont développé un mécanisme de captage d'eau de l'atmosphère durant la nuit dans des conditions favorables. Il existe des indications que les idioblastes sont impliqués dans ce mécanisme.

\section{INTRODUCTION}

The surface of a plant is the place where direct interactions between the plant body and the environment occur, and therefore plays an important role in the life strategies of land plants, especially with those plants that live under extreme climatic conditions. Consequently, features of the epidermis form an important part of character syndromes of plants such as xerophytes, e.g. the Mesembryanthemaceae, a well-known family of leaf succulent plants that inhabit the arid parts, deserts and semi-deserts, of Southern Africa.

\section{EPIDERMAL STRUCTURE}

Notwithstanding the fact that they all live in similar dry habitats, the Mesembryanthemaceae exhibit an enormous variety of epidermis types. Two distinct and quite different basic types of epidermis can be distinguished:

\footnotetext{
"Institut für Allgemeine Botanik, Universität Hamburg,
} Ohnhorststr. 18, D-2000 Hamburg 52, West Germany.
1. One type in which all 'ordinary' epidermal cells (except guard cells and subsidiary cells) are of nearly the same size. This type will be referred to as the 'xeromorphic type of epidermis' (Ihlenfeldt \& Hartmann, 1982), as it exhibits clearly those characters assumed to be typical for the epidermis of a xerophyte (Fig. 1): reduced cell lumenae, caused by thick secondary wall layers, especially of the outer cell wall; encrustation by oxalate crystals; a cutinized wall layer and a cuticle proper of considerable thickness, and a wax layer covering the cuticle. Usually the stomata are sunken. Sunken stomata are thought to decrease residual stomatal transpiration by forming antestomatal chambers (Lyshede, 1979).

2. Another type which is characterized by the occurrence of much enlarged epidermal cells (idioblasts) among the 'ordinary' epidermal cells in a more or less distinct pattern (Fig. 2). These idioblasts normally protrude above the level of the 'ordinary' epidermal cells and have been called 'papillae' (Hagen, 1873; Oberstein, 1910) or 'bladder cells' (Oztig, 1940). This type of epidermis will be called the 'idioblast type of epidermis', a term 


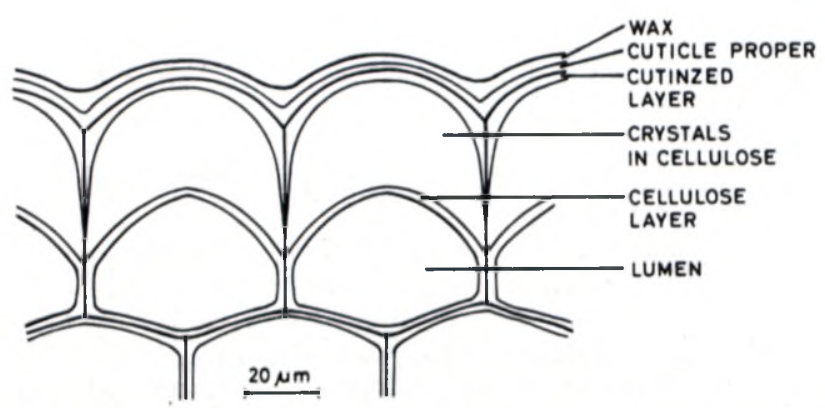

FIG. 1.-Xeromorphic type of epidermis with typical features.

derived from the most prominent feature of this type. The 'classical' xeromorphic features are not, or are very poorly, developed in this type. The outer cell wall of the epidermal cells remains thin, oxalate crystals are absent, a cutinized layer is not discernible and the cuticle is very thin $(0,5 \mu \mathrm{m}$ or less); wax is only poorly developed. This, however, does not apply to the idioblasts: in general their outer cell wall is 2-5 times thicker than that of the adjacent 'ordinary' epidermal cells, and a striking feature is that this outer cell wall is unevenly thickened, the greatest thickening found at the top of the idioblast. This special feature enables the idioblasts to change their shape to a certain degree: at times of water stress the idioblasts become flatter, their diameter increases. Consequently, if the idioblasts are of the protruding bladder type and densely crowded, the gaps between the idioblasts can become notably narrower; thus the narrow channels leading down to the stomata can be partially closed. The idioblasts exhibit further aberrant features: the outer cell wall can be encrusted by some oxalate crystals (observed by Oztig, 1940). The thin layer of cytoplasm has a foam-like appearance and contains chloroplasts and numerous mitochondria (Kramer, 1979), and in addition, some starch grains. Another notable feature is the occurrence of a certain number of pit-like cavities in the outer cell wall; these are concentrated in a zone just above the level of the 'ordinary' epidermal cells. Furthermore, the

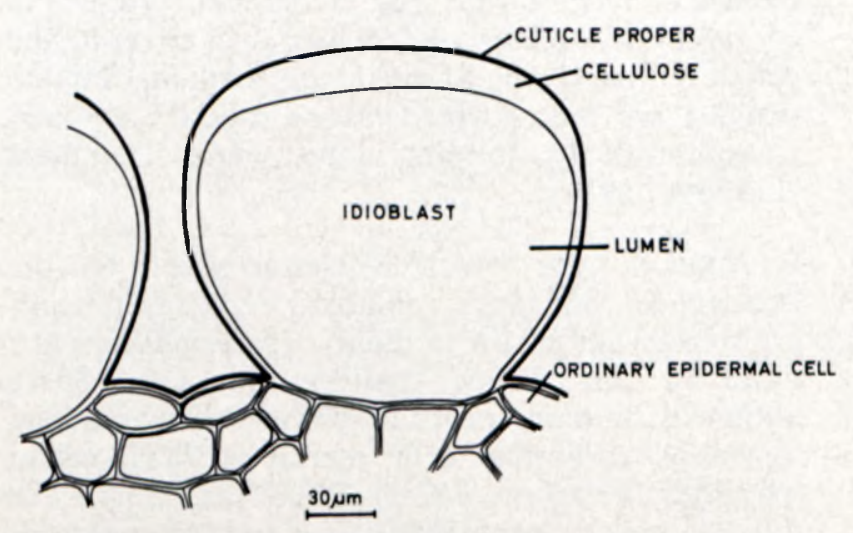

FIG. 2.-Idioblast type of epidermis with typical features. orientation of the apertures of the stomata is remarkable: the apertures are nearly always parallel to the outline of the adjacent idioblasts. Finally, in this type of epidermis, in contrast to the xeromorphic type, the stomata are never sunken.

The great variety of epidermal types described in the literature for the Mesembryanthemaceae can be shown to be a combination of one of the two basic structural types of epidermis with different size classes of sculptures; the latter can be of different origin, i.e. they are not necessarily homologous.

The surface sculptures can be classified into three distinct size classes:

I. Surface sculptures of $0,15-1 \mathrm{~mm}$ and more in diameter, visible with the naked eye (Fig. 3.1-3.4).

II. Surface sculptures of $20-50 \mu \mathrm{m}$ in diameter and 20-150 $\mu \mathrm{m}$ in length, being protuberances of epidermal cells (Fig. 4.5-4.6).

III. Surface sculptures of $1-10 \mu \mathrm{m}$ in size, consisting of the wax cover (Fig. 3.5-3.6).

In the idioblast type of epidermis, sculptures of size class $\mathrm{I}$ are formed by the idioblasts reaching more than $2 \mathrm{~mm}$ in diameter in some extreme cases (Fig. $3.1 \& 3.3$ ). Sculptures of size class II can only be developed by the idioblasts (in contrast to the xeromorphic type of epidermis, see below) (Figs 4.5 and $5.1 \& 5.3)$. These sculptures are protuberances of the idioblast cells, ranging from flat dome-like forms e.g. Aptenia N.E.Br. (Fig. 4.4) to hair-like papillae, single [e.g. Jacobsenia hallii L. Bol. (Fig. 4.5)] or paired [e.g. in the genus Trichodiadema Schwant. (Fig. 5.3)], and to branched structures resembling antlers [Anisocalyx vaginatus (L. Bol.) L. Bol. (Fig. 5.1)]. Sculptures of size class III are rare in the idioblast type of epidermis; they are represented by wax platelets that are orientated vertically [e.g. Prenia sladeniana (L. Bol.) L. Bol. (Fig. 3.5)] or by thread-like structures [in the genus Malephora N.E.Br. (Fig. 3.6)]. In contrast to sculptures of size class II, all cells of the epidermis are capable of producing these sculptures.

In the xeromorphic type of epidermis, sculptures of size class I are represented by local surface elevations, formed by groups of 'ordinary' epidermis cells and usually positioned above a huge tannin idioblast in the mesophyll below (Fig. 3.2 \& 3.4). In these elevated areas stomata are absent (e.g. Titanopsis Schwant.). Sculptures of size class II are formed by papilla-like projections of the epidermal cells; all epidermal cells (excluding guard cells) are capable of forming papillae (Fig. 4.6), but sometimes papillate epidermal cells are restricted to elevated areas (e.g. Odontophorus N.E.Br.). Sculptures of size class III are formed by the wax cover as in the idioblast type of epidermis.

\section{ECOLOGICAL SIGNIFICANCE OF THE EPIDERMAL STRUCTURES}

Obviously the complicated epidermal structures described are of ecological significance. This can be inferred from the fact that a relatively large amount of material produced by photosynthesis (strongly inhibited by the deficiency of water, which is the 

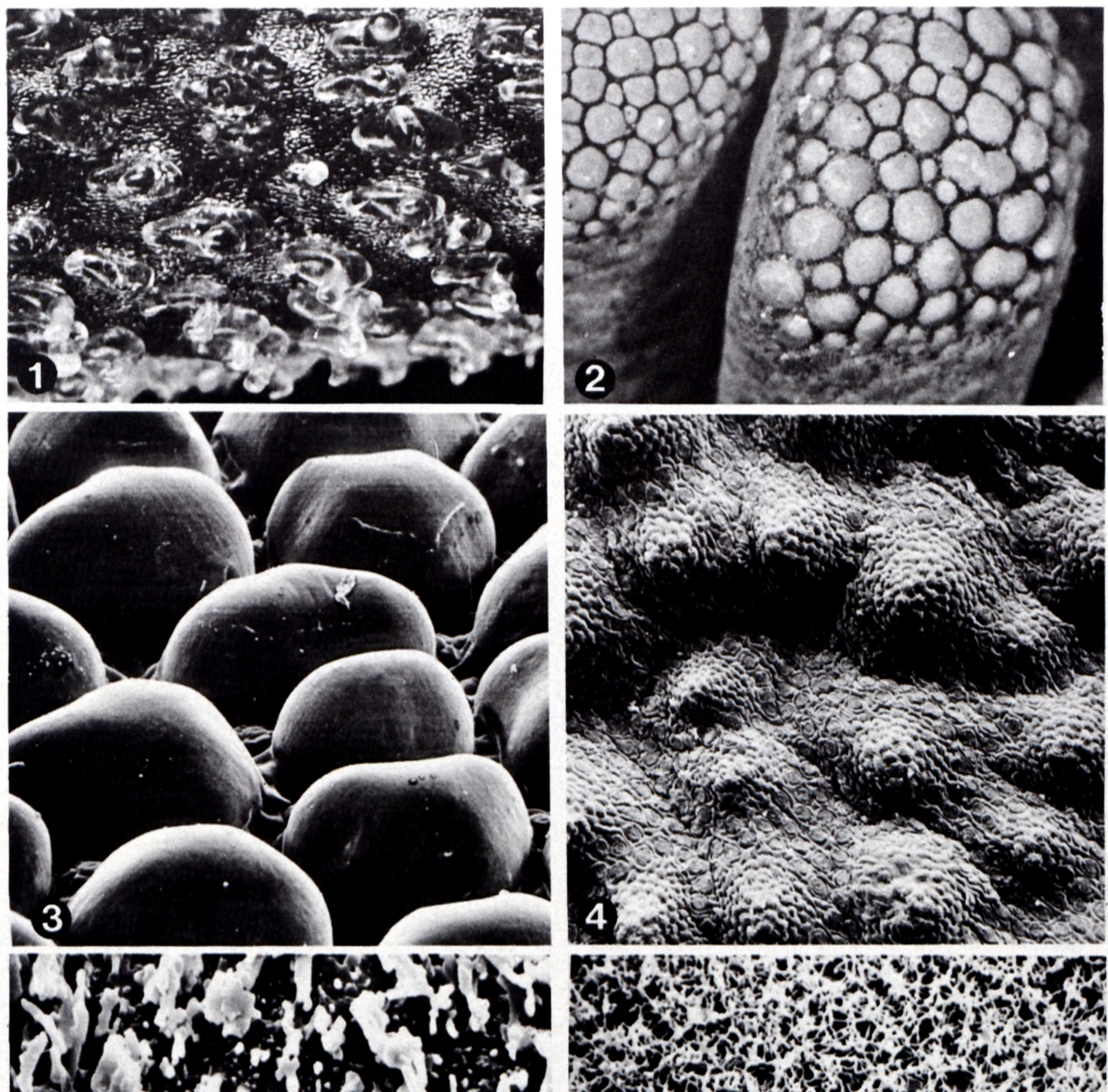

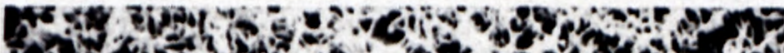

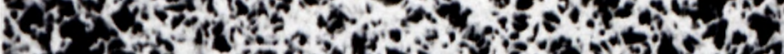

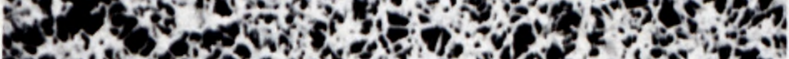

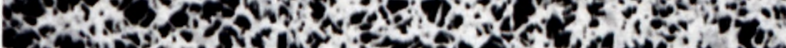

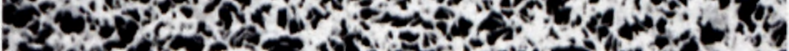

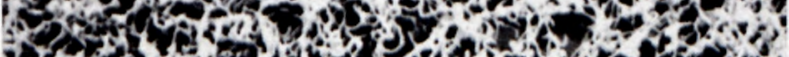

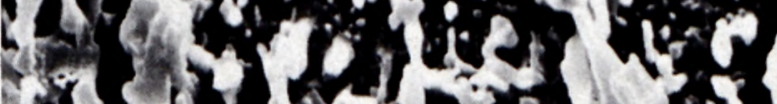

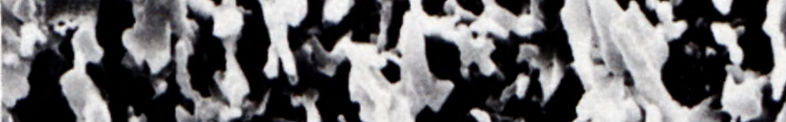

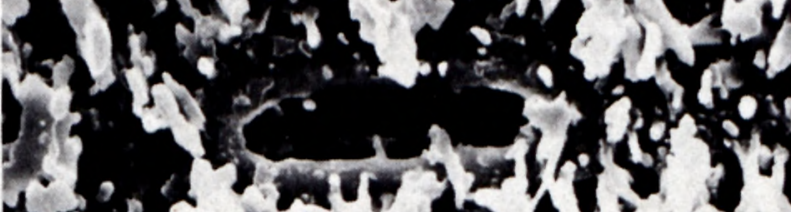

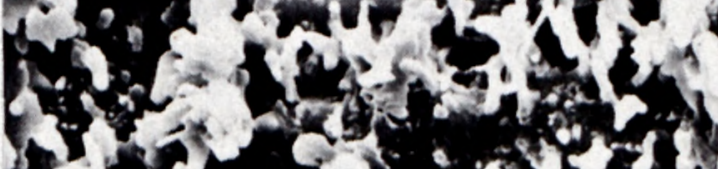

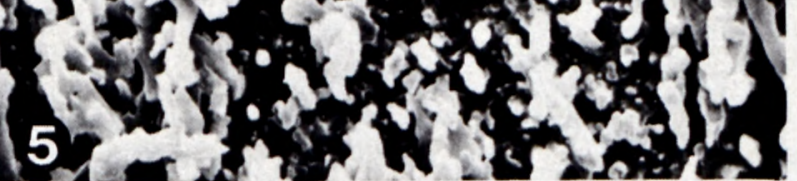

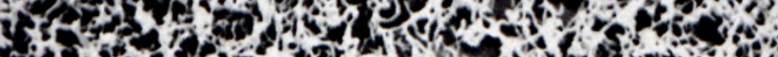

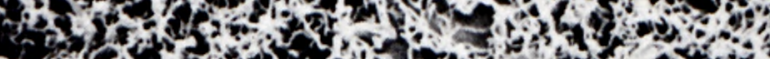

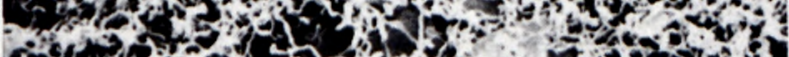

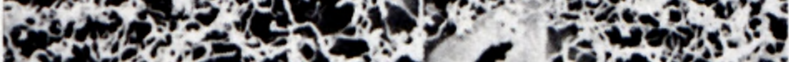

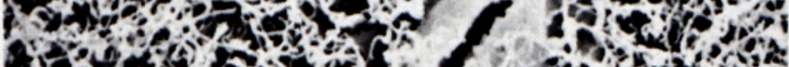

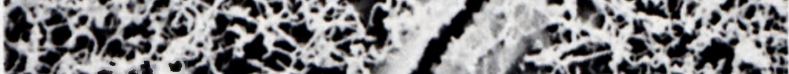
and 0

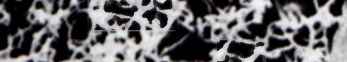

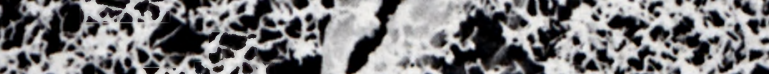

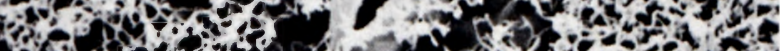

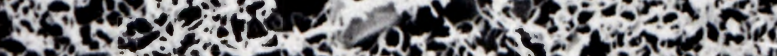

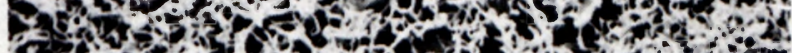

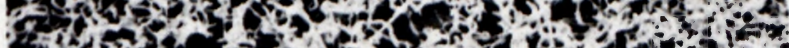

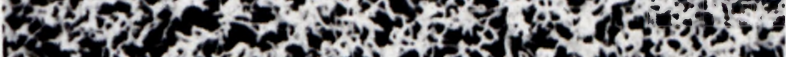

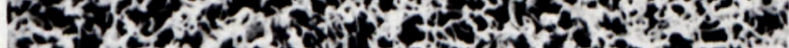
5.

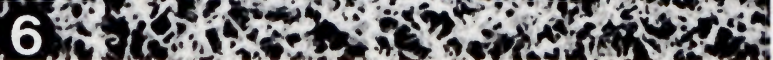

FIG. 3.-1, Monilaria chrysoleuca (Schltr.) Schwant. var. chrysoleuca. Idioblast type of epidermis. The huge idioblasts with papilla-like protuberances are $0,6 \mathrm{~mm}$ long and $0,5 \mathrm{~mm}$ high; they represent surface sculptures of size class I. Macrophotograph, $\times 2,5.2$, Titanopsis schwantesii (Dtr.) Schwant. Xeromorphic type of epidermis. The leaf tips exhibit elevations (diameter 0,5-1 mm) of the epidermis formed by groups of epidermal cells; these elevations represent surface sculptures of size class I. Macrophotograph, $\times 5.3$, Jacobsenia kolbei (L. Bol.) L. Bol. (Ihlenfeldt \& Poppendieck 6376). Idioblast type of epidermis. The SEM photograph shows the protruding idioblasts, the much smaller 'ordinary' epidermal cells and the stomata. $\times 200.4$, Stomatium sp. cf. S. bolusiae Schwant. Xeromorphic type of epidermis. The SEM photograph shows elevated areas (forming sculptures of size class I, compare Fig. 3.2) and depressed areas; the stomata are confined to the depressed areas. $\times 50.5$, Prenia vanrensburgii $\mathrm{L}$. Bol. Idioblast type of epidermis. The wax cover forms platelets representing sculptures of size class III. $\times 2000.6$, Malephora sp. (Hartmann 1460). Idioblast type of epidermis, but idioblasts much reduced (compare Fig. 5.6). The wax cover forms thread-like structures representing sculptures of size class III. $\times 2000$. 

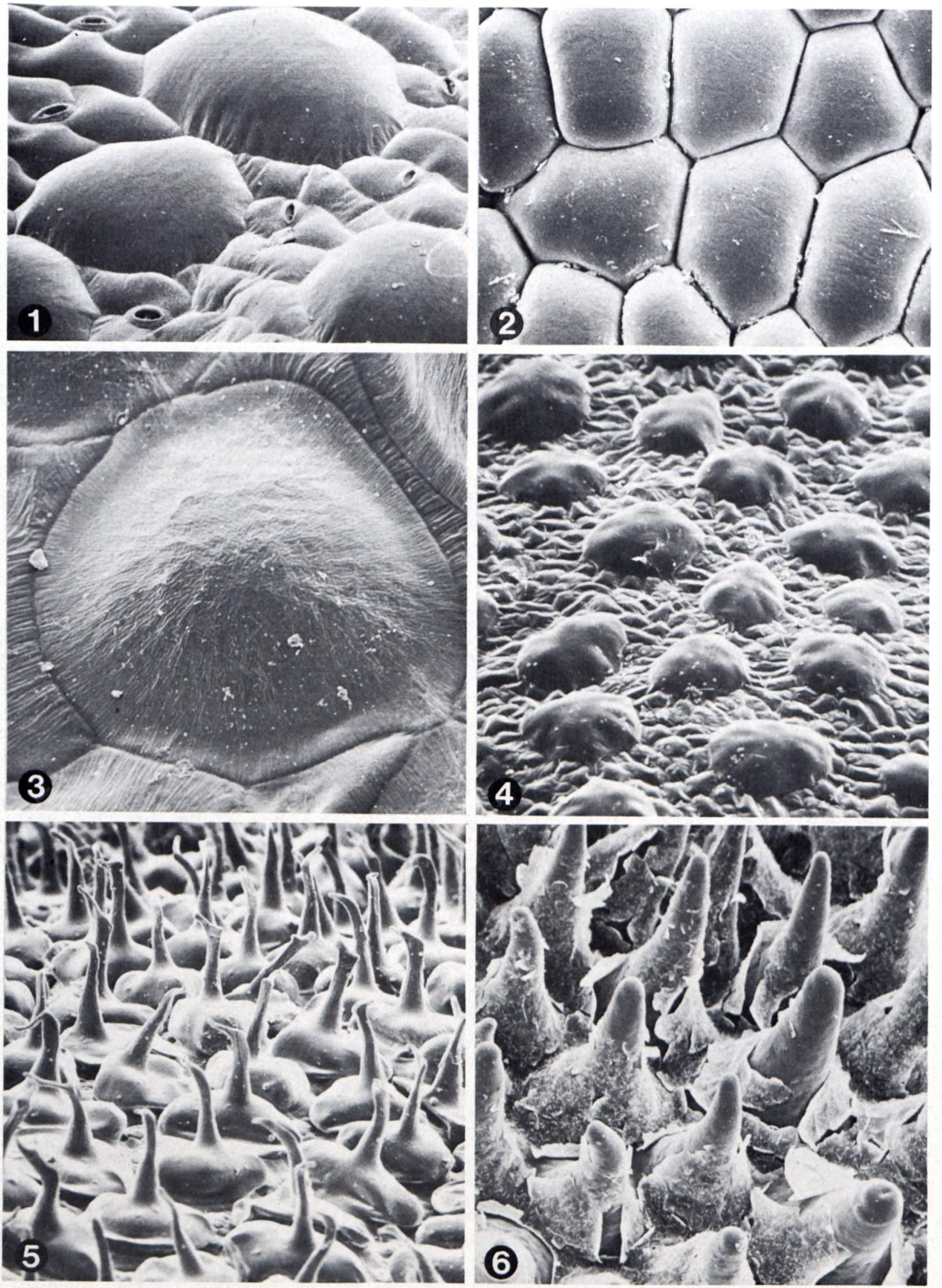

FIG. 4.-1, Prenia relaxata (Willd.) N.E. Br. Idioblast type of epidermis. The idioblasts are only slightly raised. 2, Jacobsenia kolbei (L. Bol.) L. Bol. (Hartmann 1641). Idioblast type of epidermis. The idioblasts are so densely crowded that the 'ordinary' epidermal cells and the stomata are not visible from above. Note that there is a considerable variation in the idioblast pattern within the species (compare Fig. 3.3) $\times$ 200. 3, Prenia sladeniana (L. Bol.) L. Bol. Idioblast type of epidermis. The idioblasts are only very slightly raised. $\times 500.4$, Aptenia sp. (Ihlenfeldt $\&$ Poppendieck 6362, undescribed species). Idioblast type of epidermis. The idioblasts exhibit dome-like protrusions. $\times 100.5$, Jacobsenia hallii L. Bol. Idioblast type of epidermis. The idioblasts exhibit papilla-like protuberances, which represent sculptures of size class II. Note that only the idioblasts are capable of forming papillae (compare Fig. 4.6). × 180. 6, Cheiridopsis sp. (Ihlenfeldt, Jürgens \& Bittrich 9133). Xeromorphic type of epidermis. All epidermal cells (except guard cells and subsidiary cells) form papilla-like protuberances, which represent sculptures of size class II. The wax cover is continuous (partly detached due to preparation). $\times 500$. 

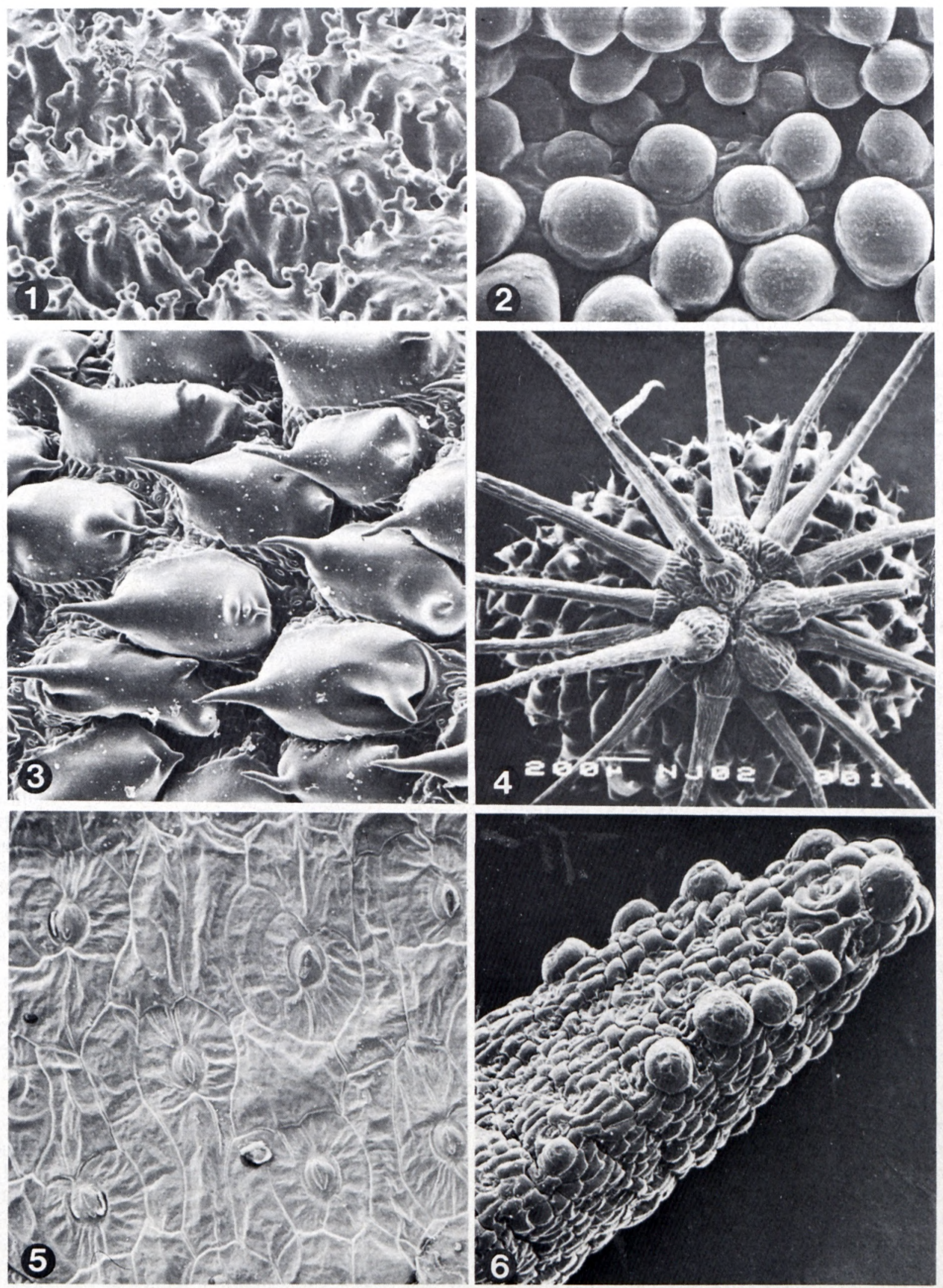

FIG. 5.-1, Anisocalyx vaginatus (L. Bol.) L. Bol. Idioblast type of epidermis. The idioblasts (sculptures of size class I) exhibit a series of branched antler-like protuberances representing sculptures of size class II. 2, Prenia sladeniana (L. Bol.) L. Bol. Idioblast type of epidermis. The margins of two leaves within the bud interlock by their idioblasts which along the margin are much more raised than on the rest of the leaf (compare Fig. 4.3). 3, Trichodiadema sp. cf. T. bulbosum (Haw.) Schwant. Idioblast type of epidermis. Each idioblast exhibits two (sometimes three) papilla-like protuberances (representing sculptures of size class II). The large one is directed towards the tip of the leaf. The adjacent 'ordinary' epidermal cells form a sort of cup around the base of each idioblast. 4, Trichodiadema sp. cf. T. bulbosum. Leaf tip with the characteristic "hair bristle' (diadema). The long hairs originate ontogenetically from idioblasts (compare Fig. 5.3) and are able to absorb water (see Ihlenfeldt, 1980) $\times 45.5$, Disphyma crassifolium (L.) L. Bol. Idioblast type of epidermis, but the idioblasts are extremely reduced (one single idioblast can be seen near the centre of the picture) $\times 500.6$, Malephora sp. (Hartmann 1879). Idioblast type of epidermis. As in Disphyma, the idioblasts are extremely reduced except along the margin of the leaf at the tip. $\times 100$. 
'normal' condition in the native habitats), is invested in these structures. The ecological significance of the sculptures can furthermore be deduced from the fact that analogous structures occur in different groups of the family, all living in similar habitats.

As far as the xeromorphic type of epidermis is concerned, this concept is consistent with the 'classical' views on ecological significance of the so-called xeromorphic features of an epidermis. The idioblast type of epidermis, however, according to current views, must be called aberrant if one takes into account, that representatives of both types of epidermis can occur sympatrically in the same extreme habitat (e.g. Oophytum N.E.Br., idioblast type of epidermis, and Argyroderma N.E.Br., xeromorphic type. Ihlenfeldt \& Hartmann 1982). Furthermore, the remarkable tendency towards an enormous enlargement of the surface of living epidermal cells by various types of protuberances is poorly understood, since xerophytes are thought to display a tendency towards reducing their surface in order to decrease water loss by cuticular transpiration.

At present we are far from a thorough understanding of the functioning of the two basic types of epidermis and of the ecological significance of certain features, especially of the sculptures. The following remarks are only tentative and more or less hypothetical; they are made to indicate possible directions of future research.

Ecophysiological investigations (Von Willert et al., 1980) have revealed that the two different basic types of epidermis apparently are the anatomical expression of two different life strategies or survival strategies under very extreme conditions. The one group (species with an epidermis of the idioblast type) may be called the 'opportunists', the other group (species with an epidermis of the xeromorphic type) the 'savers'. The 'opportunists' have a comparatively high water turnover (relying on their ability of compensating losses during the night, see below) with the advantage of a higher output from photosynthesis (which makes possible a high growth rate) on the one hand and on the other hand with the risk of death under abnormal drought conditions, when the mechanism for extracting water from the atmosphere no longer works. The 'savers' minimize their water losses under all (even under favourable) conditions; under extreme conditions, such as prolonged periods of drought, they successfully rely on their water reserves, stored in the centre of their leaves, and on the high degree of protection against water loss by the xeromorphic type of epidermis. The first group can take advantage of periods with rainfall above average and survives in periods of prolonged drought only by seeds; the second group is more successful in surviving in the form of adult individuals in periods with rainfall below average. This could cause drastic oscillations in the composition of a given plant community formed by species with both types of epidermis (and both types of life strategies). Yet, considered over a long period, the frequencies of species with different life strategies and the total amount of biomass represented by the two groups, should remain unchanged, since statistically, favourable and unfavourable periods will follow each other.

How the method of gaining water, well developed in the group with an epidermis of the idioblast type, functions, is still being examined. There are indications, that the idioblasts are involved. The ability of the idioblasts to change their shape according to water supply of the plant, has already been mentioned; in this connection, one should remember that the apertures of the stomata are nearly always parallel to the outline of the adjacent idioblasts. It might be that by changing their shape the idioblasts directly induce the opening and closing of the stomata (Von Willert, pers. comm.), i.e. that the idioblasts act as regulators of the stomata proper ('super-stomata'). Furthermore, in this connection, it appears significant that the idioblasts contain numerous mitochondria and chloroplasts, which indicates high physiological activity, at least at certain times. Notwithstanding the fact that water stored in the idioblasts can be withdrawn to compensate for extreme losses of water elsewhere in the plant, the view that the idioblasts serve an external water storage function, first expressed by Volkens (1887) and again, slightly modified and stressed by Steudle et al. (1975), certainly is too simple.

The two basic types of epidermis also exhibit differences in their optical properties affecting radiation balance. In the range of wave lengths from 400-1 $300 \mathrm{~nm}$ (i.e. all relevant wave lengths, see Eller, 1979) the idioblast type of epidermis has a low rate of reflection and a high rate of transmission. In contrast, the xeromorphic type of epidermis exhibits a high rate of reflection (probably caused by the oxalate crystals in the outer cell wall of the epidermis) and a relatively low rate of transmission (apparently due to the fact that the leaves are isolateral; light once having passed the epidermis, is reflected at the same high rate by the epidermis of the opposite side, i.e. it is 'trapped'). It should be stressed that the rate of absorption (and transmission) is in the first place determined by the diameter of tissue passed by the radiation. Therefore, the two examples given in Fig. 6 represent plants with comparable diameters of leaf; the rate of absorption is nearly equal in both species (unpublished data by Eller).

The role of the complicated sculptures is still poorly understood. Sculptures of size class III, formed by the wax cover, can influence the radiation balance as has been demonstrated in succulent plants of other families (Eller, 1979); the same may be true for the Mesembryanthemaceae. Sculptures of size class I and II may influence energy (heat) exchange between the leaf surface and the surrounding air. Barthlott \& Wollenweber (1981) have advanced the hypothesis that sculptures of these dimensions enhance turbulence on the leaf surfaces, thus reducing the heat stress of the leaves during day time. However, these sculptures may have quite a different function during the night. The water uptake from the atmosphere during the night, well developed in species with the idioblast type of epidermis, is probably triggered or enhanced by a 

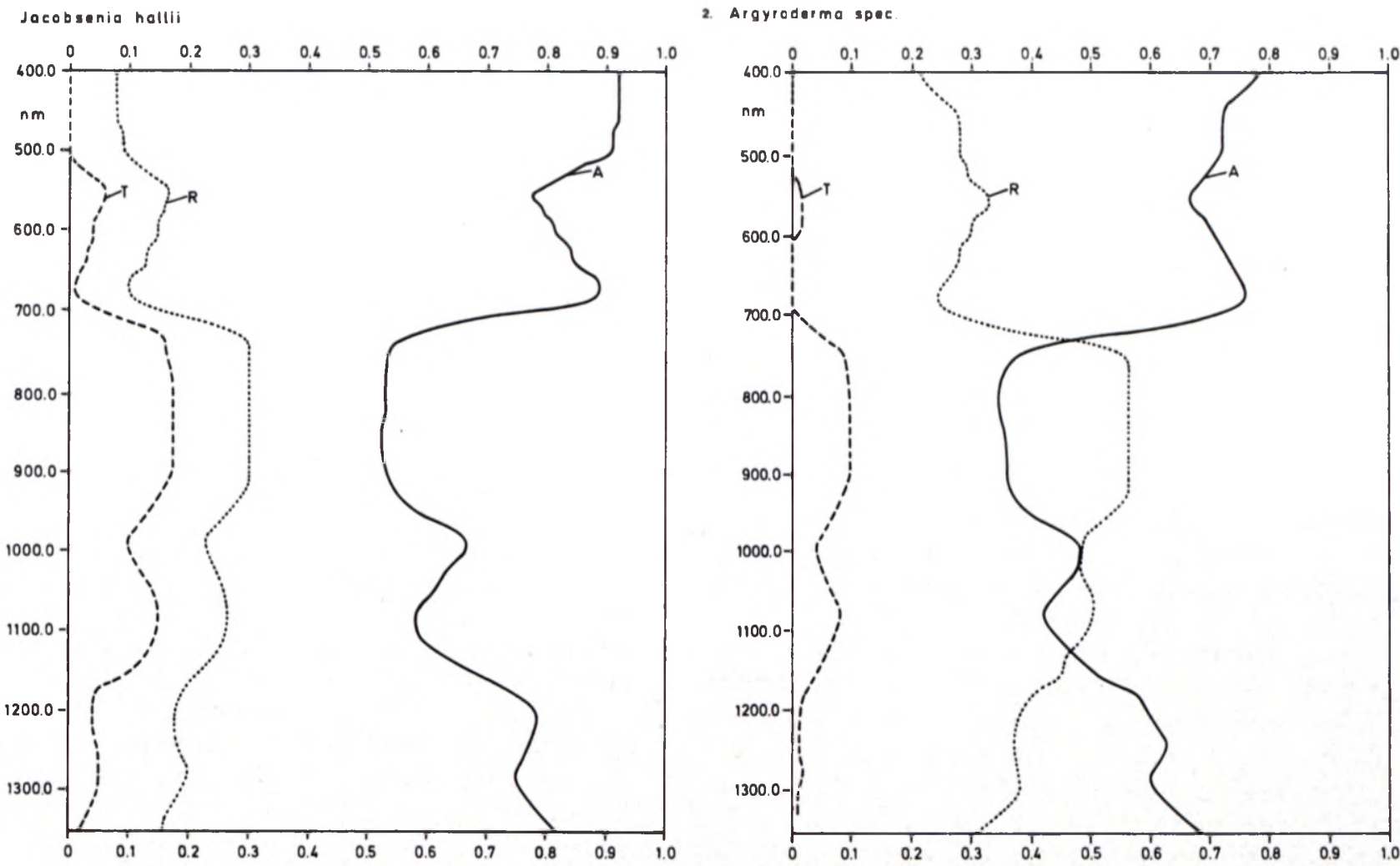

FIG. 6. - Optical properties of leaves exhibiting the two basic epidermis types. Ordinate: wave lengths in nm; abscissa: ratio. $\mathrm{T}=$ Transmission (i.e. light having passed the leaf); $\mathrm{R}=$ reflection; $\mathbf{A}=$ absorbtion. Jacobsenia hallii $\mathrm{L}$. Bol. (1) possesses an epidermis of the idioblast type (compare Fig. 4.5), whereas Argyroderma (2) possesses an epidermis of the xeromorphic type. For details compare text. (By courtesy of Dr B. Eller, unpublished data; for technical details see Eller, 1979.)

cooling down of the leaf surface to below the temperature of the surrounding air. This, obviously, is an effect of radiation, since this phenomenon can only be observed if the sky is cloudless (space acting as an energy sink). The cooling down leads to a considerable increase of relative humidity next to the surface of the leaf. Calculations (see Von Willert et al., 1980) revealed that under favourable conditions of temperature (below $15^{\circ} \mathrm{C}$ ) and of relative air humidity (above $80 \%$ ), a positive vapour gradient is established from outside the leaf to inside. These conditions occur often during night time in the native habitats, especially during the winter season. As soon as the gradient has been formed, plants with the idioblast type of epidermis very suddenly open their stomata (possibly directed by or through influence of the idioblasts, see above). As a consequence, malate formation starts and apparently the uptake of water, too. It may be suggested that the complicated sculptures of size class I and II influence temperature balance by suppressing or inhibiting microconvection on the leaf surface that should equalize differences in temperature between leaf surface and surrounding air. This presumption is supported by the observation that differences in temperature can only be measured as long as the weather is calm (Von Willert et al., 1980), which, in contrast to day time, is the usual condition during the night in the native habitats.

\section{REFERENCES}

Barthlott, W. \& Wollenweber, E., 1981. Zur Feinstruktur, Chemie und taxonomischen Signifikanz epicuticularer Wachse und ähnlicher Sekrete. Trop. u. subtrop. Pflanzenwelt 32. Mainz: Akademie der Wiss. u.d. Literatur.

ELLER, B. M., 1979. Die strahlungsökologische Bedeutung von Epidermisauflagen. Flora, Jena 168: 1-64.

HAGEN, C., 1873. Untersuchungen über die Entwicklung und Anatomie der Mesembryanthemeen. Inaugural dissertation Bonn.

IHLENFELDT, H. -D., 1980. Der Haarappatat (,Diadem”) der Gattung Trichodiadema Schwant. (Mesembryanthemaceae). Mitt. Inst. Allg. Bot. Hamburg 17: 145-163.

IhlenfeldT, H. -D. \& HARTMANN, H., 1982. Leaf surfaces in Mesembryanthemaceae. In D. F. Cutler, K. L. Alvin \& Price, C. E., The plant cuticle. Linn. Soc. Symp. Ser. 10. London.

KRAMER, D., 1979. Ultrastructural observations on developing leaf bladder cells of Mesembryanthemum crystallinum L. Flora, Jena 168: 193-204.

LYSHEDE, O. B., 1979. Xeromorphic features of three stem assimilants in relation to their ecology. Bot. J. Linn. Soc. 78 85-98.

OBERSTEIN, O., 1910. Beiträge zur Kenntnis der Gattung Mesembryanthemum. Inaugural dissertation, Breslau.

ÖzTıG, Ö. F., 1940. Beiträge zur Kenntnis des Baues der Blattepidermis bei Mesembryanthemen, insbesondere be den extrem xeromorphen Arten. Flora N.F. 34: 105-144.

Steudle, E., LUTtGe, U. \& ZimmermanN, U., 1975. Water relations of the epidermal bladder cells of the halophytic species Mesembryanthemum crystallinum. Planta 126 229-246.

VOLKENS, G., 1887. Die Flora der Ägyptisch-Arabischen Wüste. Berlin: Bornträger.

Von Willert, D. J., Brinckmann, E., Scheitler, B., Schulze, E.-D., Thomas, D. A. \& Treichel, S., 1980. Ökophysiologische Untersuchungen an Pflanzen der Namib-Wüste. Naturwissenschafien 67: 21-28. 